UDC 556.3: 631.16

DOI: http://doi.org/10.17721/1728-2713.91.11

A. Rokochinskiy, Dr. Sci. (Tech.), Prof., E-mail: a.m.rokochinskiy@nuwm.edu.ua, National University of Water and Environmental Engineering,

11 Soborna Str., Rivne, 33000, Ukraine; O. Shevchenko, Dr. Sci. (Geol.), Prof., Senior Researcher, E-mail: shevch62@gmail.com,

Taras Shevchenko National University of Kyiv, 90 Vasylkivska Str., Kyiv, 03022, Ukraine; P. Volk, Cand. Sci. (Tech.), Assoc. Prof., E-mail: p.p.volk@nuwm.edu.ua, V. Turchenyuk, Dr. Sci. (Tech.), Prof., Assoc. Prof., E-mail: fwg@ukr.net;

R. Koptjuk, Cand. Sci. (Tech.), Assoc. Prof., E-mail: r.m.koptyuk@nuwm.edu.ua; L. Volk, Cand. Sci. (Tech.), Assoc. Prof., E-mail: I.r.volk@ukr.net; National University of Water and Environmental Engineering, 11 Soborna Str., Rivne, 33000, Ukraine

\title{
HYDROGEOLOGICAL ACTION OF DRAINAGE AND DRAINAGE SYSTEMS OF POLISSIA ZONE IN CHANGING CLIMATIC CONDITIONS
}

(Представлено членом редакційної колегії д-ром геол. наук, проф. О.Є. Кошляковим)

We have analyzed various methods and models for determining and calculating drainage module. The drainage module is an important indicator of the hydrogeological effect of drainage and soil drainage. For the calculation of the drainage calculation module, an empirical, analytical, water-balance method is used, or it is accepted on the recommendations without sufficient economic and environmental justification. This does not meet the modern requirements for the creation and operation of such objects. Traditionally, the designs and parameters of agricultural drainage are determined by the drainage module. It provides the necessary conditions for the removal of excess moisture of the active soil layer in the spring (as the main calculation) and corresponds to a certain level of the calculated security of the formation of the runoff hydrograph. According to the generalized results of the research, in the calculation of drainage parameters, the values of drainage modules were taken within: for mineral soils $-0.4 \ldots 0.6 \mathrm{l} / \mathrm{s} \cdot \mathrm{ha}$, for peat soils $0.2 \ldots 0.6$ $\mathrm{I} / \mathrm{s} \cdot \mathrm{ha}$. These recommended values are not correct because then the defined drainage parameters take into account only the technological conditions of its operation. But this does not take into account the conditions of formation of economic and environmental effect within the system, and they are not economically and environmentally optimal for the calculation of the drainage system and its elements. We have performed research and evaluation of the hydrogeological effect of the drainage and drainage systems. The results of these researches showed the variability of values of drainage modules in time and space. We have also identified many influencing factors and confirmed their difference with the calculated value. A new evaluation of the effectiveness of drainage systems and the calculation of drainage modules are proposed. This evaluation includes the yield criterion for variable natural (climatic) and agricultural conditions. New optimal values of drainage modules are proposed. These values are also presented for critical conditions (maximum daily rainfall of different levels of probability).

Keywords: hydrogeological action of drainage, drainage systems, changing climatic conditions.

Problem formulation and critical review of research on the topic. As the practice and experience of technological and design solutions show in creation and operation of drainage systems (DS) and their main regulating elements (main channel, channel and side network manifold and, drainage, etc.), their future efficiency is determined by the drainage module that provides the necessary conditions for removal of excess moisture from the active layer of the soil in the spring (as the main calculation module) and corresponds to a certain level of stock calculation in hydrograph runoff formation. However, it does not always make it possible to reach the project level of economic and environmental efficiency of the drainage operation and affects its overall cost. It is known that different drainage intensity due to hydrogeological drainage action (reduction of ground water level (GWT), regulation of soil moisture, volume and time of water withdrawal etc.), by the close nature conditions, creates uneven hydrogeology, reclamation status and the fertility of the land also the resulting deviations from the optimal yield. In its turn, drainage runoff and the drainage runoff module as its defining characteristic is the main indicator of hydrogeological drainage action and is one of the main alongside with the total evaporation, which is the cost element of drained soils water balance.

Therefore, there is a need to study the question of conditions formation, drainage modules identification and substantiation that decisively influence on area drainage ability which are under DS service.

According to the practice and experience gained from the drainage development, as well as from a worthy analysis of literature sources and researches, different methods and models are used in the drainage calculations to determine the drainage runoff module, as a whole they are empirically, analytically, water-balanced determined or accepted according to recommendations without sufficient economic and environmental substantiation, which does not meet the modern requirements in the creation and operation of such facilities.

In 1913 to design drainage systems the calculating norm of runoff of $0,16 \mathrm{l} / \mathrm{f} \cdot \mathrm{ha}$ was accepted.

In 1918 A.D. Dubah, based on the general Burkley-Ziegler formula $q=\frac{A}{\sqrt[x]{F}}$, where $F$ is the drainage area (ha), gave his first calculating runoff formula for the design of drainage channels. To determine the constant values $A$ and $x$ A.D. Dubah has chosen runoff norms adopted in the draft regulation of rivers Pticha, Ippy and Stubla.

For computation of calculated drainage module B.G. Heitman and H.A. Pisarkov proposed such an empirical formula

$$
q_{0}=\frac{C H^{2}}{B^{2}}
$$

where $H$-pressure, the value of which depends on the required rate of groundwater reduction; $B$-distance between drains; $C-$ Is an empirical coefficient that depends on the type of soil (Heitman, Pisarkov, 1955).

Kostyakov A.M., based on the dynamics of groundwater supply due to the seepage precipitation, proposed to determine the calculated drainage module according to the formula (Kostyakov, 1960): 


$$
q=\frac{X \cdot \eta}{864 \cdot t \cdot \beta}
$$

where $X$-precipitation number $(\mathrm{mm})$ over time $t$ (days); $\eta$ - absorption coefficient; $\beta$ - coefficient that depends on the rate of water seepage into the soil and the rate of decrease in GWT;

The calculations according to formula (2) can be performed only having the data of the empirical coefficients $\eta$ and $\beta$. At the same time, the calculated dependence, by Kostyakov A.M., does not take into account moisture evaporation costs which leads to a significant overestimation of the values of the calculated drainage runoff module. It is the evapotranspiration, in the current situation of global warming and increasing critical depth of the GWT (Shevchenko, 2019), becomes chief external natural regulator of drainage runoff on drying-moisturizing systems.

Yangol A.M. recommended to consider the impact of evaporation on moisture that infiltrates on the groundwater level, using the certain coefficient $\left(k_{0}\right)$ and for the Ukraine conditions the next empirical formula should be taken:

$$
q_{x}=q_{0} \cdot k_{0} \cdot k_{p} \cdot k_{B},
$$

where $q_{x}$ - the calculated drainage module; $q_{0}$-run off module from the land, depending on the profile of its usage, for example, under arable land and spring pastures $0,61 \mathrm{l} / \mathrm{s} \cdot \mathrm{ha}$; for hayfields and summer pastures $-0,52 \mathrm{l} / \mathrm{s} \cdot \mathrm{ha}$; for gardens $-0,70 \mathrm{l} / \mathrm{s}$.ha, etc; $k_{0}$ - coefficient that depends on the annual precipitation; $k_{p}$ - coefficient that depends on the distance between the drains; $k_{B}$ - is the coefficient that depends on the water permeability of the soil (Yangol, 1970). However, $k_{0}$ does not take into account the differentiation of evaporation by landscape and climatic conditions.

Similar equation recommends Shkinkis Ts. N. (Shkinkis, 1981), but for the conditions of the Latvian SSR with prevalence of mineral soils:

$$
q_{x}=q_{p} \cdot k_{d} \cdot k_{t B} \cdot k_{f},
$$

Where $q_{x}$ - is the average drainage module of the calculated period at certain depths for the laying drains $t$ and

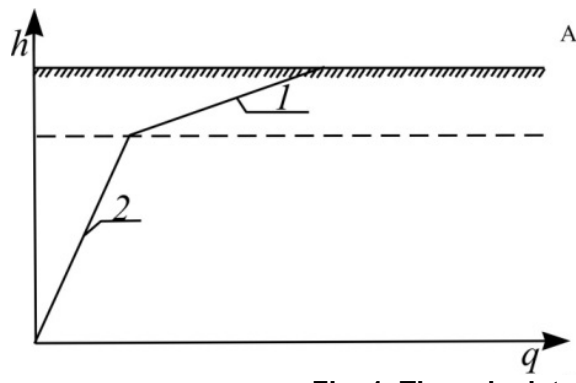

\section{A}

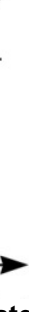

Fig. 1. The calculated scheme of the two-tier runoff model

This model, when forming the drainage module, describes the passage of moisture through two tiers (Fig. $1 \mathrm{~A}$ ), within which the runoff can be shown by linear models:

$$
\left\{\begin{array}{l}
\frac{1}{\beta_{1}} \frac{d q_{1}}{d t}=R_{(t)}-q_{1}-q_{12} \\
\frac{1}{\beta_{2}} \frac{d q_{2}}{d t}=q_{12}-q_{2} \\
q=q_{1}+q_{2} .
\end{array}\right.
$$

distance between drains $B ; k_{d}$ - coefficient that depends on climatic conditions; $k_{t B}$ - coefficient that depends on $t$ and $B$; $k_{f}$ - coefficient that depends on the soil conditions for this republic.

A.I. Ivytsky in his scientific work "Fundamentals of design and calculations of Polissya drainage systems" (Ivytskyi, 1981) on the basis of obtained data and theoretical background, suggested such dependencies for runoff modules during sowing period:

a) without taking into account the slope of the flow:

$$
q=\sigma \sqrt{h}_{n}^{3} \cdot \sqrt{F} \cdot \delta
$$

b) taking into account the slope of the flow:

$$
q=\frac{\sigma_{0} \sqrt{h}_{n}^{3} \cdot \sqrt{F} \cdot \delta}{\sqrt[5]{I}}
$$

where $q$ - is the average long-term module of the sowing period in $1 / \mathrm{sec} / \mathrm{km}^{2} ; \quad \sigma$ and $\sigma_{0}$ - coefficients equal to: $\sigma=0,00316$ and $\sigma_{0}=0,00224 ; h_{n}$ - surface flow of spring flood in $\mathrm{mm}$, determined by the map; $F$ - water intake area in $\mathrm{km}^{2} ; I$ - slope of the flow in ppm Yah; $\delta$ - coefficient which accounts the influence of wetlands and forest cover on the sowing runoff for which such expression is found

$$
\delta=\sqrt[4]{\beta+\lambda+1}
$$

where $\beta$-is the wetland of the water intake in $\% ; \lambda$-forestry in $\%$.

It is interesting to note that A.I. Ivitsky obtained a direct dependence of the seeding module from the size of the water intake area.

According to research of Tumas P.A. (1975) drainage module formation on loamy soils is very complex. As a rule, a more permeable layer is located at the top of the soil. The impact of this layer on the drain's runoff formation can be depicted by two 'tier model which is based on approximation of drain function of two lines with a fracture on the sole more permeable upper layer of soil (Fig.1).

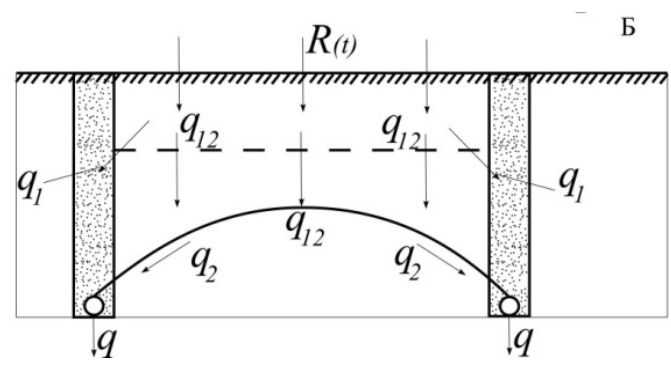

The solution of the system of equations (8) makes it possible to determine:

$$
\begin{aligned}
q_{1}= & R_{(t)}\left[\left(1-e^{-\beta_{1}}\right)+a\left(e^{-\beta_{1}}-e^{-\beta_{2}}\right)\right]+ \\
& +q_{t-1}\left[e^{-\beta_{2}}+b\left(e^{-\beta_{2}}-e^{-\beta_{2}}\right)\right]
\end{aligned}
$$$$
\text { where } \quad q_{12}=a R_{(t)}, q_{2 t-2}=b q_{t-2}
$$

$R_{(t)}$ - is the effective rainfall minus surface runoff, $a-$ is the coefficient characterizes the fraction of effective rainfall discharged through the lower soil layer; $b$ - coefficient characterizes the share of lower tier runoff in the total runoff (for the 
previous day); $\beta_{1}, \beta_{2}$ - empirical coefficients of drainage, describe its work by operation intensity of groundwater in the corresponding layers $1 /$ day.

Calculated drainage module, given in the current standards in most countries of Western Europe, USA, Japan and others is determined by the analytical method. The above-mentioned principle was followed by A.M. Kostyakov, V.G. Heitman and H.A. Pisarkov, A.I. Ivitsky, S.F. Averyanov et al.

In its turn, the analysis of this method shows that, depending on the soil and climatic conditions, the drainage module is accepted in drainage calculations within $0,4 \ldots 0,9 \mathrm{l} / \mathrm{s} \cdot \mathrm{ha}$, decreasing to $0,3 \ldots 0,6 \mathrm{l} / \mathrm{s} \cdot$ hectares for the south of Ukraine and increasing to $0,7 \ldots 0,9 \mathrm{l} / \mathrm{s} \cdot$ ha for the north and areas with average annual rainfall of $700 . . .800 \mathrm{~mm}$ or more (Ivytskyy, 1981).

Due to the more intensive use of agriculture on drained lands, widespread use of farming practices and with transition of the upper layer large part runoff to the drainage one, at the end of 70-80 years a tendency to increase the value of calculated drainage modules appeared. Similarly, in the Latvia's current regulations the meaning of drainage module was increased up to $0,7 \ldots 0,8 \mathrm{l} / \mathrm{s} \cdot$ ha (Lukianas, 1975, Lukianas and Ruminaite, 2009, Miseckaite and Gurklys, 2011).

To compare all the above mentioned, we note that the calculated drainage modulein Western Europe countries was accepted within $0,8 \ldots 4,8 \mathrm{l} / \mathrm{s} \cdot \mathrm{ha}$, with higher values $2 . . .4 \mathrm{l} / \mathrm{s} \cdot \mathrm{ha}$ specific to foothills areas and mountainous provinces with annual rainfall over $1000 \mathrm{~mm}$. (Zemes 1995, Morkunas and Ramoska, 2001, Schultz B and De Wrachien D. 2002).

According to the German standard, drainage runoff modules for collector's diameter hydraulic calculation and the distance between the drains are calculated on average annual rainfall and are accepted within $0,8 \ldots 2,0 \mathrm{l} / \mathrm{s} \cdot \mathrm{ha}$. Among European countries, the largest calculated runoff modules are accepted in Sweden - 7 I/s.ha (Schrader, 1970, Sileaka et al., 2003, Wesstrom et al., 2001.)

In USA regulations calculated drainage runoff module depending on the type of soil, crop rotation and conditions of the surface water flow is taken also within $0,8 \ldots 4,0 \mathrm{l} / \mathrm{s} \cdot$ ha. In Japan, German standards have been accepted, they were recalculated on average annual rainfall of $1000 \ldots .2800 \mathrm{~mm}$, 2,0...5,0 l/s'ha (Engelsmann, 1978).

In Belarus drainage is allowed for a full section only for 2 days, which corresponds to $0,5 \%$ of the average daily modules probability. As a result, the following drainage runoff modules that correspond to estimated probability are recommended: by the distance between drains in $B=10 \mathrm{~m}$ $q_{0}=0,82 \mathrm{l} / \mathrm{s} \cdot \mathrm{ha} ; B=14 \mathrm{~m}, q_{0}=0,68 \mathrm{l} / \mathrm{s} \cdot \mathrm{ha} ; B=20 \mathrm{~m}$, $q_{0}=0,48 \mathrm{l} / \mathrm{s} \cdot \mathrm{ha}$ (Likhachevich, 2001). The calculated percentage of fullness is thus subjectively selected, without sufficient economic and, moreover, environmental substantiations. This module thus obtained has a distinct regional character. There is no such substantiation in Ts.N. Skinkis, who for the conditions of Latvia accepts $q_{p}$ equals to $2 \%$ fullness of the year, or for the duration of the period of drying 7 days.

The disadvantage of the empirical method of determining the calculated drainage module is the approximate nature of making amendments which consider the peculiarities of the natural conditions of the drainage object and the inability to consider the full range of variable weather and climatic conditions and consequently, the possible calculated drainage modules.

Scientists point to a methodological error that is allowed in the full-scale determination of the calculated drainage module. Due to large stochastic variability of soil properties and their moisture conditions to estimate empirical values of the calculated drainage module long term monitoring of water regime of drained lands including drainage runoff are needed. By analogy with hydrogeological observations of river runoff, which is formed under the influence of similar natural factors, to determine drainage runoff $5 \ldots 20 \%$ fullness with an accuracy of not less than $20 \ldots 25 \%$ observations for $15-20$ years are needed. These long-term observations are time consuming and require significant financial costs.

In this regard, at the time analytical method for determining the drainage module, based on the determination of the amount of water withdrawn for a certain time took advantage. This principle was put as the basis of the Silesian Instruction of 1957 .

Currently, the most reasonable is recognized water-balance method of evaluation of the calculated drainage module, which is equivalent to the average daily intensity (calculated fullness) infiltration water intake to the dryers. The average daily inflow of water to the drains during the estimated period of drainage is determined by the formulas:

- when waterlogging caused by high standing GWT:

$$
q=\frac{H_{p}}{T_{p}} ;
$$

- in case of intensive groundwater inflow into the drained area and from the external catchment area:

$$
q=\frac{H_{p}}{T_{p}}+K_{c} I_{2} ;
$$

- with waterlogging, the challenge but the city of high standing GWT:

$$
q=\frac{H_{p}}{T_{p}}+K_{H} I_{H},
$$

where $H_{p}$ - the calculated height of a layer of water of a given fullness, which must be withdrawn during the calculation period; $T_{p}$ - time for which the water layer should be removed; $H_{p}, K_{c}$ - the average filtration coefficient of the waterbearing soil layer, $\mathrm{m} / \mathrm{day} ; K_{H}$-the coefficient of filtration of soils lying above the aquifer, in which the drain is laid and the bottom surface or sole of the upper well permeable layer; $I_{2}-$ intensity of inflow of soils of their waters and from the external catchment area; I is the gradient of the upward flow.

In this case, with the daily inflow of water to the drains during the billing period in all known formulas has an element of subjectivism. The latter is to determine the height of the soil layer from which water should be withdrawn during the billing period. It is considered that water is drawn from the soil surface layer to the drainage norm, although this position may not be observed if there are other elements of the drainage network, such as open channels.

On the other hand, in some years the latter is possible, but partial losses of the crop may be ecologically justified by lower capital costs for the construction of the DS. In addition, a layer of water remaining on the surface after the rise of meltwater, snow melting or heavy rainfall is accepted as a standard. The position is not taken into account when the maximum runoff and, accordingly, the minimum depths of groundwater can be observed much earlier than the seeding runoff and that even with a reduced degree of drainage, the DS can provide the required drainage norm. It is also very approximate, without sufficient reasons, the time for which the required layer of water should be removed is accepted too.

The disadvantage is also exists in the approximate nature of the estimation of the probability of precipitation and evaporation, and the lack of consistency of the calculated provisions that make up the water balance equation. 
Therefore, considering calculating distances between systematic horizontal drainage O.I. Oliynyk and V.L. Polyakov defined drainage module $(q, \mathrm{l} / \mathrm{s} \cdot \mathrm{ha})$ through the intensity $\varepsilon$ ( $\mathrm{m} /$ day) by such dependence (Olejnik and Polyakov, 1987):

$$
q=116 \cdot \varepsilon
$$

The actual value is expressed as follows:

$$
\varepsilon=\varepsilon_{i n \phi}-\varepsilon_{\text {oun }},
$$

where $\varepsilon_{i н \phi}$-is the intensity of the total infiltration feed; $\varepsilon_{\text {вun }}$ - intensity of total evaporation from the groundwater surface( amount of evaporation and transpiration).

Peculiarity of drainage calculations is fandangoing for the distance between drains on known (given) module of drainage runoff (intensity of infiltration $\varepsilon$ ), depths for laying drains, allowed GWT depths reduction on inter drained and lithology drained aquifers thickness.

According to SBN.2.4-1-99 "Reclamation Systems and Structures" (1999), the values of drainage modules $q$ ( $\mathrm{m} /$ day) are taken on the basis of regional ones or determined by the formula:

$$
q=\frac{W}{t}
$$

where $t$ - is the time of decrease of GWT to the standard of drying, days; $W$ - water's layer subjected to withdrawal $(\mathrm{m})$, is defined by the equation:

$$
W=h_{s}+J_{n d} \mu+P-E t,
$$

where $h_{s}$ - is the layer of water remaining on the surface after the flow of spring or storm water (taking into account the measures for the organization of surface runoff is assumed to be $0,01 \mathrm{~m}$ ).

For the calculation the parameters of the combined drainage-accumulation system Kozhushko L.F. defined the general module by the following formula:

$$
q_{i}=q_{H i}+q_{a i}+q_{e i},
$$

where $q_{H i}$ - module flow value of lower tier tube drains $q_{a i}$ - including part of a total drainage flow module that accumulates in the upper tier, $q_{e i}$-value module runoff of the upper tier, I/s·ha (Kozhushko, 2001).

Water-balanced method for determining the drainage flow module was improved by Muranov V.G. (Lazarchuk, Rokochinskii, Muranov, 2000) on the basis of the dependencies of O.D. Antonova (Antonov, 1974). The essence of this approach is to determine the calculated (optimum) value of the drainage module, which is accepted for each specific crop with the appropriate economic substantiation in the range from 0,1 to $2,0 \mathrm{l} / \mathrm{s} \cdot$ ha with a step change of $0,1 \mathrm{l} / \mathrm{s} \cdot \mathrm{ha}$, keeping the technological requirements (drainage of water in the spring period under the conditions of formation of the flow hydrograph of the corresponding calculated provision for drainage - from $2 \ldots 5$ to $10 \%$ provision regarding the calculated drainage flow module).

In general, the volume of water to be removed is determined by the equation

$$
W=W_{\text {ПОВ }}+W_{\Gamma в}+W_{O C}+W_{\Gamma P}-W_{E},
$$

where $W_{П о в}$ - the layer of water remaining on the surface after the snow melts; $W_{\Gamma B}-$ a layer of water that is removed from the soil when the GWT is reduced; $W_{O C}$ - layer of precipitation during the billing period; $W_{\Gamma P}$-groundwater inflow from the surrounding area; $W_{E}-$ a layer of water that has evaporated during the billing period.
In retrospective calculations, drainage flow module values were set $q_{i}$ between 0,1 and 2,0 l/s ha. The time required for reduction of GWT to on soils in spring calendar year, determined by every day calculation, based on the prediction, that the volume of water to be withdrawn equals draining capacity, considering module $q_{i}$

$$
W_{i, \mu, n}=q_{i} \theta_{i, \mu, n},
$$

where $W_{i, \mu, n}$ - is the volume of water to be discharged in the calendar year $n$, in the drainage flow module $q$, on soils with their own water output $\mu ; \theta_{i, \mu, n}$ - the time required to decrease GWT from $H_{H}$ to $H_{K}$ a calendar year $n$ if drainage is calculated by module $q_{i}$

Possible sowing period following the decline of GWT to normal drainage $H_{H}$ since full soil thawing I took 3-5 days and during evaporation during $\theta_{i, \mu, n}$ exceeds precipitation on $15 . .20 \mathrm{~mm}$ (Antonov, 1974)

Thus, by the general results of previous studies for the Ukraine Polissya Zone in the calculation of drainage parameters module" values of drainage runoff are adopted within: for mineral soils $0,4 \ldots 0,6 \mathrm{l} / \mathrm{s} \cdot$ ha, in peaty soils $0,2 \ldots 0,5 \mathrm{l} / \mathrm{s} \cdot$ ha. In its turn, these recommendations, as calculated, did not justified them selves so as defined by them drainage parameters account only the technological conditions of its work. However, the conditions for the formation of an economic and absolutely ecological effect are not sufficiently taken into account, that is, they are not economically and ecologically optimal for the calculation of DS as a whole (Rokochinsky, Volk et al., 2011, 2019).

For existing drainage and for that which is under project, the requirements for the forecasts are different and depend on the natural depth of the groundwater, drainage level, which is characterized as a rule, only through the drainage module and displays only soil drainage ability.

The hydrogeological effect of drainage and drainage ability, in contrast to the approaches mentioned above, can be considered as the natural or artificial withdrawal intensity of water from the estimated layer of soil or a certain area and to evaluate it by the indicators and parameters of the corresponding values of the drainage module. Therefore, there is an objective need to consider not only drainage and DS in general, when the drainage module reflects drainage ability of a certain drained territory taking into account channels and wired network, variable climatic, hydrogeological, agronomic, technological, technical, economic and environmental conditions as well as the type, value, productivity and profitability of cultivated agricultural crops (Volk, Rokochynskyy, 2011).

The purpose of the work: investigate the changes in the conditions of formation of drainage modules and their parameters under variable natural and agricultural land in order to clarify their calculated values in the design of reconstruction projects and new construction of DS.

\section{Outline of the main material.}

To accomplish this task, a large-scale computer-based experiment on an accelerated time scale was planned and carried out. The experiment is based on a set of forecastingimitation models regarding the basic structural and technological variables of the DS, climatic conditions of the terrain, water regime, technologies of water regulation (drainage) and productivity of the drained lands for the schematized natural, agro-technical and reclamation conditions. The model was developed at the Department of Water Engineering and Water Technology at the National University of Water and Environmental Management. Their practical 
application is regulated by the relevant industry standards of the State Agency of Ukraine (Rokochinsky et al., 2010).

Model of predictive assessment based on long-climatic conditions of the area allows you to get a typical distribution of major metrological factors (precipitation amounts, average values of temperature deficit and relative humidity), to adopt the ten-day cross section characteristic (calculated) as for heat and moisture supply during vegetation periods (Rokochinskiy, Stashuk, 2008).

$\vec{x}_{f j \tau}=\left(P_{j \tau}, \bar{T}_{j \tau}, \bar{D}_{j \tau}, \bar{H}_{j \tau}\right), f=\overline{1, n_{f}} ; j=\overline{1, n_{j}} ; \tau=\overline{1, n_{\tau}}$

where $\vec{x}_{f j \tau}$ - the state vector (data sets) of the main metrological factors together $\{f\}, f=\overline{1, n_{f}},\left(n_{f}=4\right)$ : amounts of rainfall $\bar{P}_{j \tau}(\mathrm{mm})$, the mean values of temperature $\bar{T}_{j \tau}$ $\left({ }^{\circ} \mathrm{C}\right)$, deficit $\bar{D}_{j \tau}(\mathrm{mm})$ and relative humidity $\bar{H}_{j \tau}(\%)$ - with estimated time intervals (day, pentad, decade) together $\{\tau\}$, $\tau=\overline{1, n_{\tau}}$ during the vegetation season (April-October) $j$-years of observations together $\{j\}, j=\overline{1, n_{j}}$.

The model of water regime and water regulation technology is based on the use of the usual "simple" equation of water balance in the integral form for the calculation layer of soil (CLS) $h=0,5 \mathrm{~m}$ on the adopted scheme, structure of calculations and the step of its discretization and allows to evaluate the mode and technological parameters with water regulation of drained land for multiple changing conditions of real object including, an assessment of drainage and DS in general by drainage module as for the different levels of its efficiency (Rokochynskyi, Stashuk, 2011).

To accept structure of calculations and a given discretization step $\tau, \tau=\overline{1, n_{\tau}}$ ( pentad, week, decade - according to the implementation of the model of meteorological regimes) the model is as follows:

$$
\left\{\begin{array}{l}
W h_{\tau}=W h_{\tau-1}+P_{\tau}-E_{\tau} \pm V h_{\tau}+m_{\tau}, \quad \tau=\overline{1, n_{\tau}}, m^{3} / h a \\
H g_{\tau}=H g_{\tau-1} \pm \Delta H g, \quad \tau=\overline{1, n_{\tau}}, \quad m,
\end{array}\right.
$$

where in model (22) $W h_{\tau}, W h_{\tau-1}$ are the corresponding reserves of productive moisture of the CLS at the end of the estimated current $\tau$ and previous $(\tau-1)$ time intervals, at a given initial value $W h_{0}, P_{\tau}$ - effective precipitation over time $\tau$; $E_{\tau}$ - the corresponding value of the total evaporation; $V h_{\tau}-$ the amount of moisture exchange of the CLS $h$ with the lower layers and GWT in the form of power (+) $V V h_{\tau}$ or infiltration iHфільтрації $(-) V I h_{\tau} ; m_{\tau}-$ irrigation rate with the appropriate method of moistening; $\mathrm{Hg}$ - depth of groundwater; $\Delta \mathrm{Hg}-$ change in groundwater level over time $\tau$

The model of effective yield on dehumidified lands is based on models of local climatic conditions, water regime and water management technologies, also allows to determine yields by the long-term forecast. This model is presented in the form of a complex model of multiplicative type, which is expressed through the product of functions of influence of determining factors on the formation of the crop by the system of corresponding coefficients (Rokochinsky and Shalay, 2017).

$$
Y_{k \omega g s p}=Y_{\omega k p}^{F} \cdot \prod_{i=1}^{n_{i}} K_{i}=Y_{\omega k p}^{F} \cdot K_{1} \cdot K_{2} \cdot K_{3} \cdot K_{4} \cdot K_{5} \cdot K_{6},
$$

$$
i=\overline{1, n}_{i}
$$

where $Y_{\omega k p}^{F}$ - climatically provided yield during the vegetation period $k$-culture; $K_{1}$ - coefficient of decrease in yield by soil bonus $g\left(0 \leq K_{1} \leq 1\right) ; K_{2}$ is the coefficient of increase in the yield by the introduction of fertilizers $\left(K_{2}>1\right.$ but $0<K_{1}$, $\left.K_{2} \leq 1\right) ; K_{3}-$ the coefficient of decrease of yield at deviation of sowing period or renewal of vegetation from the optimum $\left(0 \leq K_{3} \leq 1\right) ; K_{4}$ - coefficient of influence of current natural reclamation conditions (climate $\omega, p$ and water regulation technologies $s$ ) of the period of vegetation of the crop on the formation of yield $\left(0 \leq K_{4} \leq 1\right)$; $K_{5}$ is the coefficient of decrease of yield at deviation of the harvesting period from the optimum $\left(0 \leq K_{5} \leq 1\right) ; K_{6}$ is the coefficient of yield reduction due to losses during collection and transportation $\left(0<K_{6} \leq 1\right)$.

The machine experiment based on predictive-simulation modeling was performed under the conditions and averaged data of climate change (meteorological stations or posts in the West Polisia zone of totality $\{\omega\}, \omega=\overline{1, n}_{\omega}$; the periods calculated on the terms of heat and humidity of vegetation of the totality $\{p\}, p=\overline{1, n}_{p}$ very wet periods ( $\left.p=10 \%\right)$, wet periods $(p=30 \%)$, average-wet periods $(p=50 \%)$, dry periods $(p=70 \%)$, very dry periods ( $p=90 \%$ ); for the two main most common types of soil in the Polesia region of Ukraine: sod-gleyed sandy-loam soils $\left(k_{\phi}=0,8 \mathrm{~m} /\right.$ day $)$ and peat soils ( $\left.k_{\phi}=0,4 m / d a y\right)$; culture of project crop-rotation: winter wheat with yield $(40 \mathrm{c} / \mathrm{ha})$, the share of culture in crop-rotation $0,2 \%$; potatoes ( $400 \mathrm{c} / \mathrm{ha}$ ), $0,3 \%$, perennial grasses (400 c/ha) 0,5\%; water regulation methods of totality $\{s\}, s=\overline{1, n_{s}},(s=1-$ drainage $)$.

On the basis of predictive-simulation modeling, the variable character of the values of drainage modules formed during the period of operation of the drainage system by crops, soils and years in the Western Polesia region of Ukraine was determined (Fig. 2).

By the complex of forecast-simulation models (21-23) the dynamics and values of the drainage flow average modules given in Fig. 2 were determined they show that under different weather and climatic conditions, growing different agricultural crops on different soils a significant change of their values in time period and space is observed.

Determined by the complex of forecasting-simulation models (Rokochynsky, Stashuk, 2011), the dynamics and values of the average drainage modules, which are presented in Fig. 2, show that for different weather and climatic conditions, when growing different crops on different soils, there is a significant change in their values over time and space.

In the sowing period of the accounting years, the values of drainage modules for grain and perennial grasses for mineral soils are $0,40 \ldots 0,62 \mathrm{l} / \mathrm{s} \cdot \mathrm{ha}$, and for peat soils $-0,74 \ldots$ $0,96 \mathrm{l} / \mathrm{s} \cdot \mathrm{ha}$, respectively for potatoes $0,40 \ldots 0,62 \mathrm{I} \mathrm{l} / \mathrm{s} \cdot \mathrm{ha}$ and $0,4 \ldots 0,96 \mathrm{l} / \mathrm{s} \cdot \mathrm{ha}$.

During the growing season, the dynamics and values of drainage modules are determined by the mode and intensity of rainfall by year, as well as the type of soil. Thus, for mineral soil the modules are $0,25 \ldots 0,02 \mathrm{l} / \mathrm{s} \cdot \mathrm{ha}$; for peat soil $0,30 \ldots 0,015 \mathrm{l} / \mathrm{s} \cdot \mathrm{ha}$. Changes in the average values of drainage modules, which are formed during the period of operation of drainage systems in terms of changing climatic conditions and cultivated crops for sod-gleyed sandy soils and peat soils of the Polesiazone are presented in Table 1. 

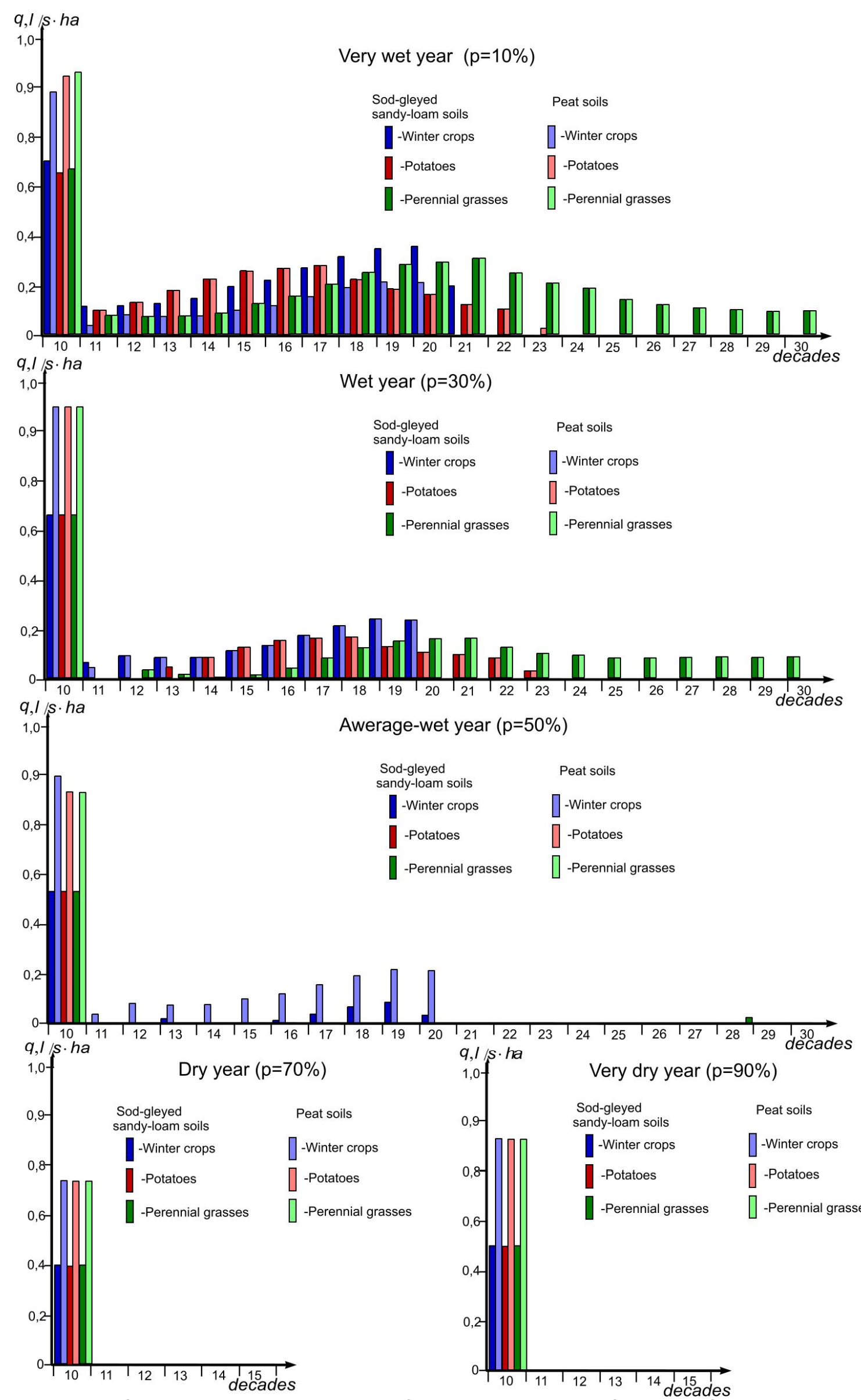

Fig 2. Values of average drainage modules that are formed during the period of operation of the drainage system for the main crops, for mineral and peat soils under changing climatic conditions of the Polissia region of Ukraine 
Generalized results on the variability of the average values of drainage modules, which are formed during the period of operation of drainage systems by variable weather-climatic, soil and agro-reclamation conditions of the Polesia region of Ukraine

\begin{tabular}{|c|c|c|c|c|c|c|c|}
\hline \multirow{3}{*}{ Culture } & \multirow{3}{*}{$\begin{array}{c}\text { Part of } \\
\text { culture in } \\
\text { crop-rotation }\end{array}$} & \multicolumn{5}{|c|}{ Calculated drainage modules, I/s·ha } & \multirow{3}{*}{$\begin{array}{c}\text { Average } \\
\text { values } \\
\text { I/s.ha }\end{array}$} \\
\hline & & \multicolumn{5}{|c|}{ Calculated years with probability, $p, \%$} & \\
\hline & & 10 & 30 & 50 & 70 & 90 & \\
\hline \multicolumn{8}{|c|}{ Mineral soils } \\
\hline Winter crops & 0,2 & $\frac{0,62-0,17}{0,41}$ & $\frac{0,52-0,18}{0,32}$ & $\frac{0,46-0,02}{0,16}$ & $\frac{0,45-0}{0,11}$ & $\frac{0,40-0}{0,06}$ & $\frac{0,41-0,03}{0,21}$ \\
\hline Potatoes & 0,3 & $\frac{0,57}{0,38}-\frac{0,09}{38}$ & $\frac{0,52-0,02}{0,28}$ & $\frac{0,46-0,02}{0,11}$ & $\frac{0,45-0}{0,10}$ & $\frac{0,40-0}{0,06}$ & $\frac{0,41-0,01}{0,19}$ \\
\hline $\begin{array}{l}\text { Perennial } \\
\text { grasses }\end{array}$ & 0,5 & $\frac{0,59-0,08}{0,51}$ & $\frac{0,53-0,06}{0,35}$ & $\frac{0,47-0,02}{0,12}$ & $\frac{0,44-0}{0,10}$ & $\frac{0,41-0}{0,06}$ & $\frac{0,42-0,01}{0,23}$ \\
\hline $\begin{array}{l}\text { On the system } \\
\text { as a whole }\end{array}$ & 1,0 & $\frac{0,59-0,10}{0,45}$ & $\frac{0,52-0,06}{0,32}$ & $\frac{0,47-0,02}{0,12}$ & $\frac{0,44-0}{0,10}$ & $\frac{0,41-0}{0,06}$ & $\frac{0,48-0,03}{0,21}$ \\
\hline \multicolumn{8}{|c|}{ Peat soils } \\
\hline Winter crops & 0,2 & $\frac{0,96-0,17}{0,46}$ & $\frac{0,86-0,18}{0,39}$ & $\frac{0,81-0,02}{0,25}$ & $\frac{0,75-0}{0,18}$ & $\frac{0,74-0}{0,11}$ & $\frac{0,82-0,07}{0,28}$ \\
\hline Potatoes & 0,3 & $\frac{0,92-0,09}{0,43}$ & $\frac{0,86-0,02}{0,35}$ & $\frac{0,84-0}{0,20}$ & $\frac{0,81-0}{0,18}$ & $\frac{0,74-0}{0,12}$ & $\frac{0,83-0,02}{0,26}$ \\
\hline $\begin{array}{l}\text { Perennial } \\
\text { grasses }\end{array}$ & 0,5 & $\frac{0,93-0,08}{0,56}$ & $\frac{0,86-0,06}{0,42}$ & $\frac{0,84-0}{0,20}$ & $\frac{0,81-0}{0,18}$ & $\frac{0,74-0}{0,12}$ & $\frac{0,84-0,03}{0,30}$ \\
\hline $\begin{array}{c}\text { On the system } \\
\text { as a whole }\end{array}$ & 1,0 & $\frac{0,94-0,10}{0,50}$ & $\frac{0,86-0,07}{0,39}$ & $\frac{0,83-0,05}{0,21}$ & $\frac{0,80-0}{0,19}$ & $\frac{0,74-0}{0,12}$ & $\frac{0,83-0,03}{0,28}$ \\
\hline
\end{tabular}

Note: $0,62-0,17$ - maximum and minimum values of drainage modules;

0,41 - average values of drainage modules.

The obtained results clearly show that the averaged values of the drainage module under the studied conditions, as in the previous case, have a pronounced variable character as for to the changing climatic conditions during the billing years, the type of crops grown and the type of soil. At the same time, its value, both as for the selected main factors and DS in whole differs significantly, first of all, from the maximum current values and values during the growing season more than several times, which determines the need to take this into account when designing projects of reconstruction, construction and operation of this kind of objects.

Absolute values of the drainage modules under the conditions of their formation in the dynamics and averaged form as for the climatic, agro-technical and soil conditions of the Polisia zone do not reflect the duration and corresponding levels of drainage efficiency and DS as a whole in specified zone. Therefore, to characterize the different levels of DS operation efficiency the values of drainage module totality are divided by us into $\left\{q_{r}\right\}, r=\overline{1, n}_{r}$ ( $r=1$ - environmental, $r=2-$ technological, $r=3$ - economic) in the spring billing period and drainage of the territory (low, medium, high) with the corresponding levels of productivity (profitability and values) of cultivated crops $U_{k}^{r}=f\left(Y_{k}^{r}\right),\left(U_{k}^{(1)}-\right.$ low, $U_{k}^{(2)}-$ medium, $U_{k}^{(3)}$ - high) and the values of the maximum deviation of the sum of average daily air temperatures accumulated from the date of the optimal sowing period or the renovation of vegetation $\sum \hat{T}_{k r}^{b}$ in the area of their biological optimum (Fig. 3).

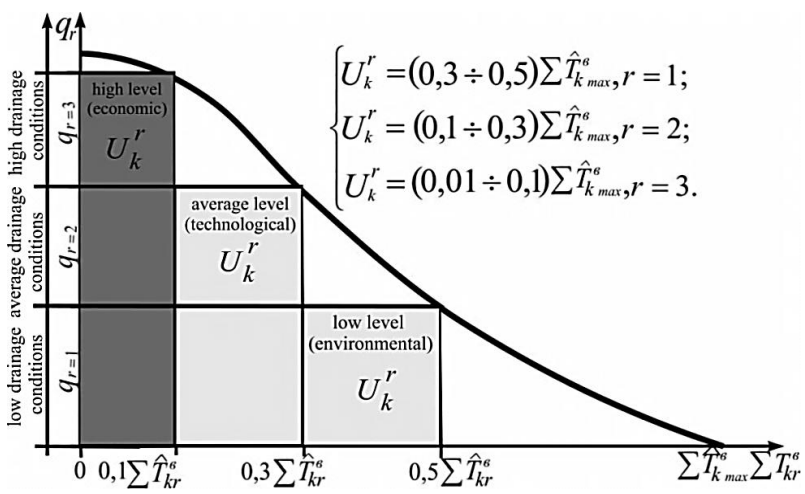

Fig. 3. The general dependence scheme $q_{r}, r=\overline{1, n}_{r}$ of $\sum \hat{T}_{k r}^{b}$ for $k$ - this culture considering environmental, technological and economic efficiency levels of DSand drainage ability

$$
q_{k}^{r}=f_{2}^{\prime}\left(U_{k}^{r}, \sum \hat{T}_{k r}^{b}\right) .
$$

In this form, function (24) reflects the relationship between the different levels of DS operation efficiency totality $\left\{q_{r}\right\}, r=\overline{1, n}_{r}(r=1$ - environmental, $r=2$ - technological, $r=3$-economic) in the spring billing period, the drainage ability of the territory (low, medium, high) and the levels of productivity (profitability and values) of cultivated crops $U_{k}^{r}=f\left(Y_{k}^{r}\right),\left(U_{k}^{(1)}-\right.$ low, $U_{k}^{(2)}-$ medium, $U_{k}^{(3)}-$ high $)$ with the corresponding values of the maximum deviation of the sum of average daily air temperatures accumulated from the date of the optimal sowing date or the renovation of vegetation in zone of their biological optimum $\sum \hat{T}_{k r}^{b}$. 
Based on the above given models and diagrams with defining and changing drainage modules totality $\left\{q_{k g p \tau}\right\}$

for each crop $k=\overline{1, n_{k}}$, soil $g=\overline{1, n_{g}}$, calculated under conditions of heat and humidity of vegetation periods $p=\overline{1, n_{p}}$, calculated time intervals (decade) $\tau=\overline{1, n_{\tau}}$, indicators of drainage and DS operation duration in general for existing variable conditions, which describe various aspects of their work under the influence of multiple variables natural farming and reclamation conditions of a real object can be determined (Rokochynskyy, Volk, 2013, 2019).

The indicator of total duration of drainage and DS operation as a whole during the billing growing season is defined as

$$
\theta_{p}^{q}=\frac{t_{p \tau}^{q}}{t_{p \tau}} p=\overline{1, n_{p}}, \tau=\overline{1, n_{\tau}} .
$$

Similarly, an indicator of the duration of drainage and DS operation at the appropriate level of their efficiency during the billing growing season

$$
\begin{gathered}
\theta_{r k g p}^{q}=\frac{t_{r k g p \tau}^{q}}{t_{k g p \tau}}, r=\overline{1, n_{r}}, k=\overline{1, n_{k}} g=\overline{1, n_{g}}, \\
p=\overline{1, n_{p}}, \tau=\overline{1, n_{\tau}},
\end{gathered}
$$

where $t_{r k g p \tau}^{q}$ - the duration of drainage and DS operation on different levels of efficiency $\{r\}, r=\overline{1, n_{r}}$ for the changing conditions of the object studied as $k=\overline{1, n_{k}}, g=\overline{1, n_{g}}$, $p=\overline{1, n_{p}}, \tau=\overline{1, n_{\tau}}$, days; $t_{k g p \tau}-$ the duration of the billing growing season of the cultivated crop, days.

Then, taking into account (25) and (26), the drainage and DS operation duration indicator for each level of their efficiency considering to the culture, soil and system as a whole within the project lifetime of the facility in general can be defined as

$$
\theta_{s v}^{q}=\sum_{g=1}^{n_{g}} \sum_{k=1}^{n_{k}}\left(\sum_{p=1}^{n_{p}} \theta_{r k g p}^{q} \cdot \alpha_{p}\right) \cdot f_{k} \cdot f_{g} .
$$

Performed evaluation of drainage efficiency and DS operation in the investigated conditions according to the corresponding "duration indicators" is presented in the form of appropriate diagrams (Fig. 4).

Obtained evaluation efficiency of the DS operation for typical conditions and averaged data of climate change Polisia area on different levels of performance show that on average ten-day conditions formation of precipitation and corresponding values of drainage modules $q_{k g p \tau}$, while growing perennial grasses, winter cereals and potatoes, duration the growing season is 214 days (100\%), of which the lifetime of the DS $-60 \%$, including those with different levels of efficiency: Environmentally friendly - $39 \%$, technological $15,5 \%$, economical $-5,5 \%$. In critical conditions $q_{k g p \tau}^{\prime}$, for the same duration of growing season (100\%), the lifetime of the drainage and DS is $68 \%$, considering different levels of its efficiency, environmental $-24 \%$ for production $-6,5 \%$, economic - 9,5\%, allowable critical - 15,5\% and in critical mode - does not exceed $5 \%$, which is quite clear.

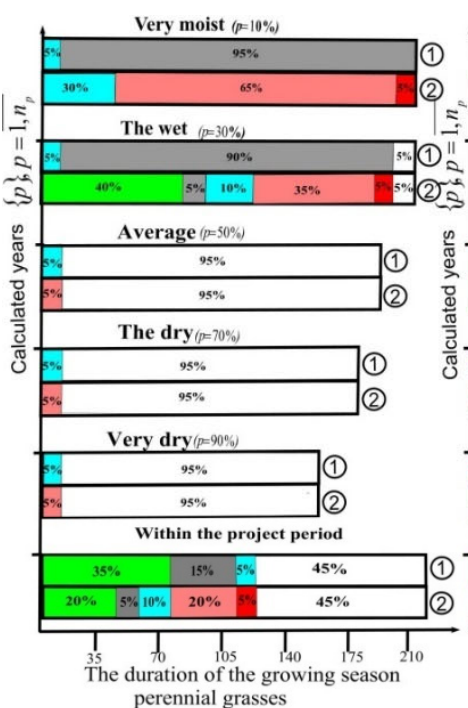

perennial grasses

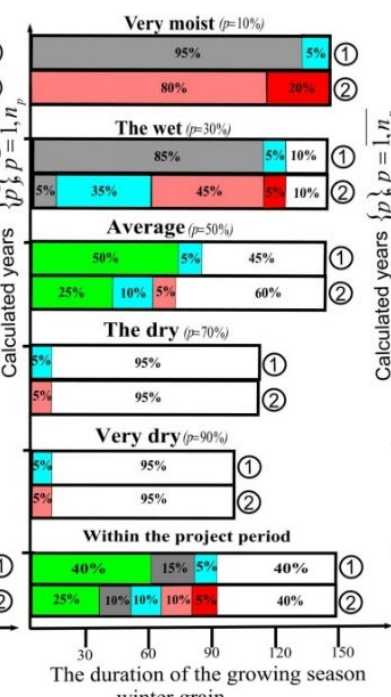

winter grain

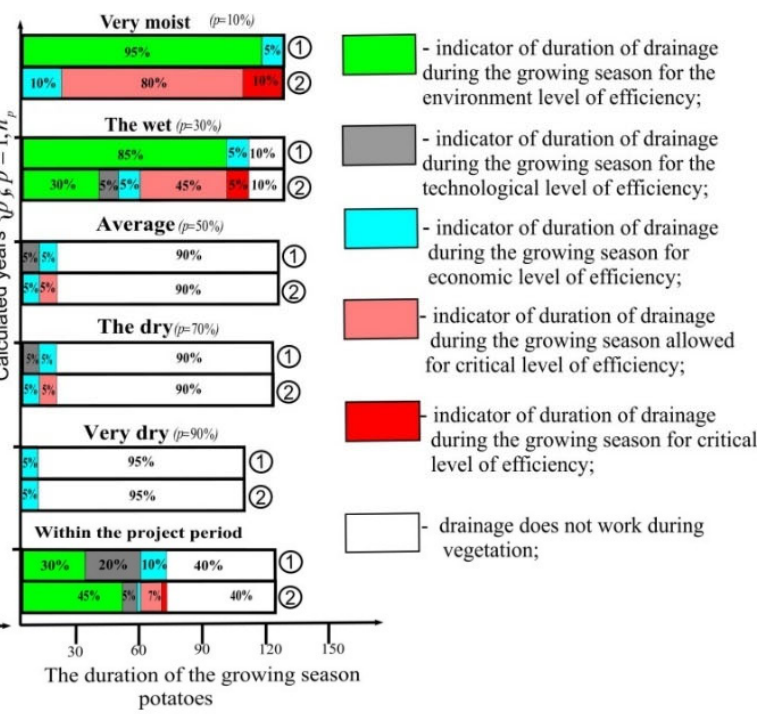

Within the system
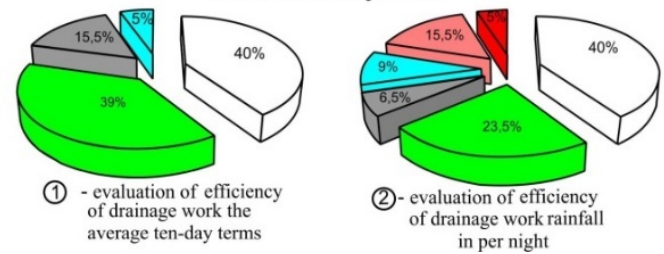

Fig. 4. Evaluation efficiency of drainage and DS operation by certain calculated data of drainage module

With climate changing, more often situations arise when the DS operates in critical conditions, a change in the nature and intensity of rainfall (ten-day precipitation falls instantly per day) occur. Then a dramatic rise in the GWT can occur and a drainage module may be formed that exceeds its calculated value. In this case, projected drainage may not cope with the removal of excess moisture from the soil, a permissible or critical soil moisture occurs, which leads to crop losses. In this case, the waste of the yield from short time raise of GWT to the depth of $0,5 \mathrm{~m}$ for $2-3$ days up $10 \ldots 20 \%$, to a depth of $0,6 \mathrm{~m}-8 \ldots .14 \%$ and $0,7 \mathrm{~m}-5 \ldots 10 \%$.

Evaluation of DS effectiveness in critical conditions is performed by a method similar to the one stated previously. At the same time, instead of the values of the average ten- 
day drainage modules determined by the conditions of formation of the corresponding sums over the decade, the average daily values should be considered when the ten-day precipitation falls in one day. Here, indicators of the duration of the permissible and critical periods of drainage and DS operation in general, when the projected drainage cannot cope with the work and the permissible or critical soil mois- ture for cultivated crops, are determined similarly to the considered indicators of the duration of their work. The generalized results of the estimation of the efficiency of the DS operation in the conditions investigated in the fallout of daily maximums of precipitation of different provision, which form the critical conditions of drainage and DS operation, are given in Table 2.

Efficiency of drainage of the investigated object in critical conditions

at the fall of daily maximums precipitation with different reserves

\begin{tabular}{|c|c|c|c|c|c|c|c|c|}
\hline \multirow{2}{*}{ Region } & \multirow{2}{*}{$\begin{array}{c}\text { Value } \\
\text { of indicators }\end{array}$} & \multicolumn{6}{|c|}{ Estimatedreserves $p, \%$} & \multirow{2}{*}{$\begin{array}{l}\text { Averaged values of critical periods } \\
\text { of wetting of cultivated crops, days }\end{array}$} \\
\hline & & $5 \%$ & $10 \%$ & $30 \%$ & $50 \%$ & $70 \%$ & $90 \%$ & \\
\hline \multirow{4}{*}{ Rivne } & $P_{\tau}, \mathrm{mm}$ & 89 & 73 & 49 & 42 & 31 & 21 & \multirow{4}{*}{$6-4$} \\
\hline & $P_{\tau}^{\prime}, \mathrm{mm}$ & 47 & 33 & 12 & 6 & 0 & 0 & \\
\hline & $q_{0} l / s$ ha & 0,65 & 0,65 & 0,65 & 0,65 & 0,65 & 0,65 & \\
\hline & $t$ (days) & 8,4 & 5,8 & 2,2 & 1,1 & 0 & 0 & \\
\hline
\end{tabular}

Obtained results show that when using the operating DS in critical conditions acceptable moisture supply to grow crops in most cases is provided - when the stock of daily maximum precipitation does not exceed $30 \%$.

\section{Conclusion}

Based on the research results, the analysis of hydrological action of the drainage and the drainage system in the Polesia area was performed. This analysis showed that for different climatic conditions and different crops on different soils there is a change in their values in time. At the same time, its value for different climatic, agrotechnical and climatic conditions and in the drainage system differs from the maximum values and values during the growing season more than a few times. The values of drainage modules in the spring for grain and grass on mineral soils are $0,38 \ldots 0,68 \mathrm{l} / \mathrm{s} \cdot \mathrm{ha}$, and on peat soils are $0,65 \ldots 0,94 \mathrm{l} / \mathrm{s} \cdot \mathrm{ha}$; for potatoes on mineral soils are $0,40 \ldots 0,62 \mathrm{l} / \mathrm{s} \cdot \mathrm{ha}$ and on peat soils are $0,38 \ldots 0,96 \mathrm{l} / \mathrm{s} \cdot \mathrm{ha}$. During the growing season, the dynamics and values of drainage modules for mineral soil, they are $0,25 \ldots 0, .020 \mathrm{l} / \mathrm{s} \cdot \mathrm{ha}$; for peat soil is $0,30 \ldots 0,015 \mathrm{l} / \mathrm{s} \cdot \mathrm{ha}$.

Evaluation of the efficiency of drainage systems for different levels of productivity showed that water supply conditions and the length of the growing season are good for perennial grasses, winter crops, and potatoes under the average decade conditions of precipitation and values of drainage modules. The value of drainage modules in the cultivation of perennial grasses, winter crops, and potatoes, the duration of the growing season is 214 days $(100 \%)$, of which the total service life of the drainage system is $60 \%$, including different levels of the system efficiency: environmental level - $39 \%$, technological level - 15,5\%, economic level - 5,5\%. In critical conditions, the total service life of drainage and drainage systems is $68 \%$. This includes different levels of its efficiency: environmental level - $24 \%$, technological level $-6,5 \%$, economic level $-9,5 \%$, acceptable critical level - 15,5\%, and at the critical level is less than $5 \%$.

Список використаних джерел

Антонов, А.Д. (1974). Исследование посевного срока северо-запада Украины. Авторефр. дисс...канд. техн. наук. Ровно.

Волк, П.П., Рокочинський, А.М. (2011). Обґрунтування модуля дренажного стоку в оптимізаційних розрахунках сільськогосподарського дренажу на еколого-економічних засадах. Вісник національного університету водного господарства та природокористування, 2 (54), 3-10.

Гадзало, Я.М., Сташук, В.А., Рокочинський, А.М. (ред.) (2017). Меліорація та облаштування Українського Полісся. Т. 1. Київ; Рівне; Херсон: Олді плюс.

Гейтман, В.Г., Писарьков, К.А. (1955). Осушение сельскохозяйственных земель. Москва.

ДБН В.2.4-1-99.(1999). Меліоративні системи та споруди. Київ.

Ивицкий, А.И. (1981). Установление расстояний между дренами. Дополнение № 1 к руководству по проектированию осушительных систем сельскохозяйственного назначения. Минск.

Кожушко, Л.Ф. (2001). Удосконалення дренажних систем. Рівне.
Костяков, А.Н. (1960). Основы мелиораций. Москва.

Лазарчук, М.О., Рокочинський, А.М., Муранов, В.Г. (2000). Оптимізація параметрів основних елементів осушувальних систем за економіко-математичним методом. Зб. наук. праць: Вісник Рівненського державного технічного університету, 4 (6), 66-72.

Лихацевич, А.П. (2001). Мелиорация земель Белоруси. Минск.

Лукянас, А.Д. (1975). Опыт осушения земель закрытым дренажем. Москва.

Олейник, А.Я., Поляков, В.Л. (1987). Дренаж переувлажненных земель. Київ.

Рокочинський, А.М. (2010). Наукові та практичні аспекти оптимізації водорегулювання осушуваних земель на еколого-економічних засадах. За ред. Ромащенка М.І. Рівне.

Рокочинський, А.М., Волк П.П. та ін. (2013). Науково-методичні рекомендації до обґрунтування оптимальних параметрів сільськогосподарського дренажу на осушуваних землях за економічними та екологічними вимогами. Рівне.

Рокочинський, А.М., Галік, О.І., Сташук, В.А., Фроленкова, Н.А., Волощук, В.А. та ін. (2008). Посібник до ДБН В.2.4-1-99 "Меліоративні системи та споруди" (Розд. 3. Осушувальні системи). Метеорологічне забезпечення інженерно-меліоративних розрахунків у проектах будівництва й реконструкції осушувальних систем. Рівне.

Рокочинський, А.М., Сташук, ВА. Дупляк, В Д. Фроленкова, Н.А та ін. (2011). Тимчасові рекомендації з прогнозної оцінки водного режиму та технологій водорегулювання осушуваних земель у проектах будівництва й реконструкції меліоративних систем. Рівне.

Тумас, Р.А. (1975). Водно-балансовые расчеты дренажа на суглинистых грунтах в Литовской ССР. Автореф. дисc. д-р. c-2. наук. Каунас.

Шевченко, А.Л., Осадчий, В.И., Нестеровский, В.А. (2019). Режим, водообмен и ресурсы подземных вод Полесья и Лесостепи в контексте глобальных изменений климата. Сборник мат-лов IV Межд. науч.-пр. конфр. "Актуальные проблемы наук о Земле. Исследования трансараничных регионов", 12-14 сент. 2019, Брест, 1, 33-37.

Шкинкис, Ц.Н. (1981). Гидрологическое действие дренажа. Ленинград. Шрейдер, В.А. (1970). Осушение земель закрытым дренажем. Москва. Энгельсманн, Р. (1978). Руководство по дренажу. Москва.

Янголь, А.М. (1970). Двустороннее регулирование влажности при осушении. Москва.

Kudakas, V., Pocienè, A., Urbonas, R. (1998). Klimatiniu veiksniu jtaka dirvožemio drègmei ir drenažo nuotèkiui [The effect of climatic factors on soil moisture and drainage flow]. Žemès ūkio mokslai, 2, 61-65.

Lukianas, A., Ruminaitè, R. (2009). Periodiškai šlapių žemių sausinimo drenažu jtaka upių nuotėkiui. Journal of environmental engineering and landscape management, 17(4), 226-235.

Miseckaite, O.,Gurklys, V. (2011). The trends of drainage runoff change in loam soils during a multi-year period. Environmental engineering, 8th International Conference, May 19-20. Vilnius, Lithuania, 625-629.

Morkūnas, V.; Ramoška, E. (2001). Drenažo nuotėkio reguliavimo tyrimai [Drainage run-off regulatory investigations]. Vandens ūkio inžinerija, 16 (38), 53-59.

Rokochinskiy A., Volk P. et al. (2019a). Forecaste destimation of the efficiency of agricultural drainage on drained lands. Journal of Water and Land Development, 40, Issue 1, 149-153. DOI:https://doi.org/10.2478/jwld2019-0016.

Rokochinskiy A., Volk P. et al. (2019, b). Evaluation of climat echangesand their accounting for developing the reclamation measures in Western Ukraine. Scientific Review Engineering and Environmental Sciences, 28, 1 (83), 3-13. DOI:10.22630/PNIKS. 2019.28.1.1.

Schultz, B., De Wrachien, D. (2002). Irrigation and Drainage systems research and development in the 21st century. Irrigation and drainage, 51, 311-327.

Šileika, A.S., Gužys, S. (2003). Drainage runoff and migration of mineral elements in organic and conventional cropping systems. Agronomic, 23, 633-641.

Wesstrom, I., Messing, I., Linner, H., Lindstrom, J. (2001). Controlled drainage - effects on drain outflow and water quality. Agricultural Water Management, 47, 85-100. 
Žemės, L. (1995). Hidrometrinis metraštis. Drenažo ir paviršiaus nuotẻkis [Hydrometer year book. Drain age and surface runoff]. Kaunas-Noreikiškès. References

Antonov, A.D. (1974). Research of a sowing line of the northwest of Ukraine. Extended abstract of Candidate's thesis (Tech. Sci.). Rivne. [in Russian]

DBN V.2.4-1-99. (1999).Reclamation systems and structures. Kyiv. [in Ukrainian]

Engelsmann, R. (1978). Drainage guide. Moscow. [in Russian]

Geytman, V.G., Pisarkov, K.A. (1955). Drainage of agricultural land.

Moscow: Selhoizdat. [in Russian]

Hadzalo, Ya.M., Stashuk, V.A., Rokochinskiy, A.M. (Edc.). (2017).

Reclamation and arrangement of Ukrainian Polissya. B. 1. Kherson: Oldi plus. [in Ukrainian]

Ivitskiy, A.I. (1981). Establishing Drain Distance. Supplement No.1 to the Design Guide for Agricultural Drainage Systems. Minsk: Uradzhay. [in Russian] Kostyakov, A.N (1960). Fundamentalsoflandreclamation. Moscow: Gos. ed. agricultural. literature. [in Russian]

Kozhushko, L.F. (2001). Improvement of drainage systems. Rivne. [in Ukrainian]

Kudakas, V., Pocienè, A., Urbonas, R. (1998). Klimatinių veiksnių jtaka dirvožemio drègmei ir drenažo nuotèkiui [The effect of climatic factors on soil moisture and drainage flow]. Žemés ūkio mokslai, 2, 61-65.

Lazarchuk, M.O., Rokochinskiy, A.M., Muranov, V.G. (2000). Optimization of parameters of the main elements of drainage systems by economic and mathematical method. Bulletin of Rivne State Technical University, 4(6), 6672. [in Ukrainian]

Lihatsevich, A.P. (2001). Land reclamation of the lands of Belarus. Minsk: BelNIIMiL. [in Russian]

Lukianas, A., Ruminaitè, R. (2009). Periodiškai šlapių žemių sausinimo drenažu jtaka upiu nuotėkiui. Journal of environmental engineering and landscape management, 17(4), 226-235.

Lukianas, A.D. (1975). The experience of land drainage by closed drainage. Moscow. [in Russian]

Miseckaite, O.,Gurklys, V. (2011). The trends of drainage runoff change in loam soils during a multi-year period. Environmental engineering,8th International Conference, May 19-20. Vilnius, Lithuania, 625-629.

Morkūnas, V.; Ramoška, E. (2001). Drenažo nuotėkio reguliavimo tyrimai [Drainage run-off regulatory investigations]. Vandens ūkio inžinerija, 16 (38), 53-59.

Oleynik, A.Ya., Polyakov, V.L. (1987). Waterlogged land drainage. Kyiv: Naukova dumka. [in Russian]

Rokochinskiy A., Volk P. et al. (2019, a). Forecaste destimation of the efficiency of agricultural drainage on drained lands. Journal of Water and Land Development, 40, Issue 1, 149-153. DOI:https://doi.org/10.2478/jwld2019-0016.
Rokochinskiy A., Volk P. et al. (2019, b). Evaluation of climat echangesand their accounting for developing the reclamation measures in Western Ukraine. Scientific Review Engineering and Environmental Sciences, 28, Issue 1 (83), 3-13. DOI:10.22630/PNIKS.2019.28.1.1.

Rokochinskiy, A.M. (2010). Scientific and practical aspects of optimization of water regulation of drained lands on ecological and economic principles. Rivne. [in Ukrainian]

Rokochinskiy, A.M., Halik, O.I., Stashuk, V.A., et al. (2008). Manual to DBN B.2.4-1-99 "Reclamation systems and structures" (Section 3. Drainage systems). Meteorological support of engineering and reclamation calculations in projects of construction and reconstruction of drainage systems. Rivne. [in Ukrainian]

Rokochinskiy, A.M., Stashuk, V.A., Dupliak, V.D., Frolenkova, N.A. et al. (2011). Interim recommendations on the forecast assessment of the water regime and technologies of water regulation of drained lands in projects of construction and reconstruction of reclamation systems. Rivne. [in Ukrainian]

Rokochinskiy, A.M., Volk, P.P. et al. (2013). Scientific and methodical recommendations for substantiation of optimal parameters of agricultural drainage on drained lands according to economic and ecological requirements. Rivne. [in Ukrainian]

Schultz, B., De Wrachien, D. (2002). Irrigation and Drainage systems research and development in the 21st century. Irrigation and drainage, 51, 311-327.

Shevchenko, A.L., Osadchiy, V.I., Nesterovsky, V.A. (2019). Regime, water exchange and groundwater resources of Polesia and Forest-Steppe in the context of global climate change. Mater. IV International.scientificpractical conf. "Actual problems of Earth sciences. Studies of cross-border regions", September 12-14, 2019, Brest, 1, 33-37.

Shkinkis, Ts.N. (1981). Hydrological drainage action. Leningrad Gidrometeoizdat. [in Russian]

Shreyder, V.A. (1970). Land drainage by closed drainage. Moscow. [in Russian]

Šileika, A.S.; Gužys, S. (2003). Drainage runoff and migration of mineral elements in organic and conventional cropping systems. Agronomic, 23, 633-641.

Tumas, R.A. (1975). Water-balance calculations of drainage on loamy soils of the Lithuanian SSR. Extended abstract of Doctor's thesis (Agri. Sci.) Kaunas. [in Russian]

Volk, P.P., Rokochinskiy, A.M. et al. (2011). Substantiation of the drainage runoff module in optimization calculations of agricultural drainage on ecological and economic bases. NUWEE Bulletin, 2(54), 3-10. [in Ukrainian]

Wesstrom, I., Messing, I., Linner, H., Lindstrom, J. (2001). Controlled drainage - effects on drain outflow and water quality. Agricultural Water Management, 47, 85-100.

Yanhol, A.M. (1970). Two-way humidity control for drainage. Moscow. [in Russian]

Žemès, L. (1995). Hidrometrinis metraštis. Drenažo ir paviršiaus nuotèkis [Hydrometer year book. Drain age and surface runoff]. Kaunas-Noreikiškès. Надійшла до редколегії 15.07.2020

A. Рокочинський, д-р техн. наук, проф.,
E-mail: a.m.rokochinskiy@nuwm.edu.ua,

Національний університет водного господарства та природокористування,

вул. Соборна, 11, м. Рівне, 33000, Україна;

О. Шевченко, д-р геол. наук, проф., ст. наук. співроб.

E-mail: shevch62@gmail.com,

Київський національний університет імені Тараса Шевченка

вул. Васильківська, 90, м. Київ, 03022, Україна;

П. Волк, канд. техн. наук, доц.,

E-mail: p.p.volk@nuwm.edu.ua;

В. Турченюк, д-р техн. наук, доц., проф.,

E-mail: fwg@ukr.net;

Р. Коптюк, канд. техн. наук, доц.,

E-mail:r.m.koptyuk@nuwm.edu.ua;

Л. Волк, канд. техн. наук, доц.,

E-mail: I.r.volk@ukr.net;

Національний університет водного господарства та природокористування,

вул. Соборна, 11, м. Рівне, 33000, Україна

\section{ГІДРОГЕОЛОГІЧНА ДІЯ ДРЕНАЖУ ТА ДРЕНАЖНИХ СИСТЕМ ЗОНИ ПОЛІССЯ У ЗМІННИХ КЛІМАТИЧНИХ УМОВАХ}

Проведено аналіз літературних джерел щодо різних методів і моделей з визначення та розрахунку модуля дренажного стоку як визначального показника гідрогеологічної дії дренажу і дренованості території. Для обчислення розрахункового модуля дренажного стоку застосовують емпіричний, аналітичний, водно-балансовий методи або приймають його за рекомендаціями без достатнього економічного та екологічного обґрунтування, що не відповідає сучасним вимогам при створенні та функціонуванні такого роду об'єктів. Традиційно конструкції та параметри сільськогосподарського дренажу визначаються за розрахунковим модулем дренажного стоку, який забезпечує необхідні умови відведення зайвої вологи активного шару ґрунту у весняний період (як основний розрахунковий) і відповідає певному рівню розрахункової забезпеченості формування гідрографа стоку. За узагальненими результатами досліджень при розрахунку параметрів дренажу значення модулів дренажного стоку брались у межах: для мінеральних ґрунтів 0,4...0,6 л/с-га, для торф'яних - 0,2...0,6 л/с·га. Ці рекомендовані значення не виправдали себе, оскільки визначені за ними параметри дренажу враховують тільки технологічні умови його роботи. Але при цьому недостатньо враховані умови формування економічного і абсолютно екологічного ефекту в межах системи, що не дозволяє вважати ці модулі оптимальними. Виконані нами дослідження й оцінка гідрогеологічної дії дренажу та дренажних систем показали значну мінливість значень модулів дренажного стоку в часі й просторі, виявили значну кількість чинників, що на них впливають, підтвердили їхню невідповідність прийнятим розрахунковим значенням. У зв'язку із цим запропоновано новий підхід до оцінки ефективності дії дренажних систем і визначення модулів дренажного стоку - за критерієм формування врожайності за змінних природних (у т.ч. кліматичних) і агротехнічних умов. Наведено нові оптимальні розрахункові значення модулів дренажного стоку, у т.ч. для критичних умов - при випадінні добових максимумів опадів різної забезпеченості.

Ключові слова: модулі стоку, ґрунтові води, гідрогеологічна дія дренажу, дренажні системи, змінні кліматичні умови, ґрунти. 
А. Рокочинский, д-р техн. наук, профр.,

E-mail: a.m.rokochinskiy@nuwm.edu.ua,

Национальный университет водного хозяйства и природопользования,

ул. Соборная, 11, г. Ровно, 33000, Украина;

А. Шевченко, д-р геол. наук, проф., ст. науч. сотр.,

E-mail: shevch62@gmail.com,

Киевского национального университета имени Тараса Шевченко,

ул. Васильковская, 90, г. Киев, 03022, Украина;

П. Волк, канд. техн. наук, доц.,

E-mail: p.p.volk@nuwm.edu.ua;

В. Турченюк, д-р техн. наук, доц., проф.,

E-mail: fwg@ukr.net;

P. Коптюк, канд. техн. наук, доц.,

E-mail: r.m.koptyuk@nuwm.edu.ua;

л. Волк, канд. техн. наук, доц.

E-mail: I.r.volk@ukr.net;

Национальный университет водного хозяйства и природопользования,

ул. Соборная, 11, г. Ровно, 33000, Украина

\section{ГИДРОГЕОЛОГИЧЕСКОЕ ДЕЙСТВИЕ ДРЕНАЖА И ДРЕНАЖНЫХ СИСТЕМ ЗОНЫ ПОЛЕСЬЯ В ИЗМЕНЧИВЫХ КЛИМАТИЧЕСКИХ УСЛОВИЯХ}

Проведен анализ литературных источников по различным методам и моделям определения и расчета модуля дренажного стока как определяющего показателя гидрогеологического действия дренажа и дренированности почвы и территории. Определено, что для вычисления расчетного модуля дренажного стока применяют эмпирический, аналитический, водно-балансовый метод или принимают его по рекомендациям без достаточного экономического и экологического обоснования, что не соответствует современным требованиям при создании и функционировании такого рода объектов. Традиционно конструкции и параметры сельскохозяйственного дренажа определяются по расчетным модулям дренажного стока, который обеспечивает необходимые условия отвода лишней влаги активного слоя почвы в весенний период (как основной расчетный) и соответствует определенному уровню расчетной обеспеченности формирования гидрографа стока. По обобщенным результатам исследований при расчете параметров дренажа значения модулей дренажного стока принимались в пределах: для минеральных почв 0,4...0,6 л/с·га, на торфяных почвах 0,2...0,6 л/с·га. Эти рекомендуемые значения как расчетные не оправдали себя, поскольку определенные по ним параметры дренажа учитывают только технологические условия его работы. Но при этом недостаточно учтены условия формирования экономического и абсолютно экологического эффекта в рамках системы, то есть они не являются экономически и экологически оптимальными. Выполненные нами исследования и оценка функциональной эффективности дренажа и дренажных систем показали значительную изменчивость значений модулей дренажного стока во времени и пространстве, обнаружили значительное количество факторов на них влияющих, подтвердили их несоответствие принятым расчетным значениям. В связи с этим предложен новый подход к оценке эффективности действия дренажных систем и определения модулей дренажного стока - по критерию формирования урожайности в переменных природных (в т.ч. климатических) и агротехнических условиях. Приведены новые оптимальные расчетные значения модулей дренажного стока, в т.ч. для критических условий - при выпадении суточных максимумов осадков различной обеспеченности.

Ключевые слова: модули стока, грунтовые воды, гидрогеологическое действие дренажа, дренажные системы, переменные климатические условия, почвы. 